\title{
Polycyclic Aromatic Hydrocarbons in Costal Sediments and Indian Halibuts of Asaluyeh, Kangan, Khark, Emam Hasan and Bushehr Coasts, Iran: Distribution Pattern and Health Risk Assessment
}

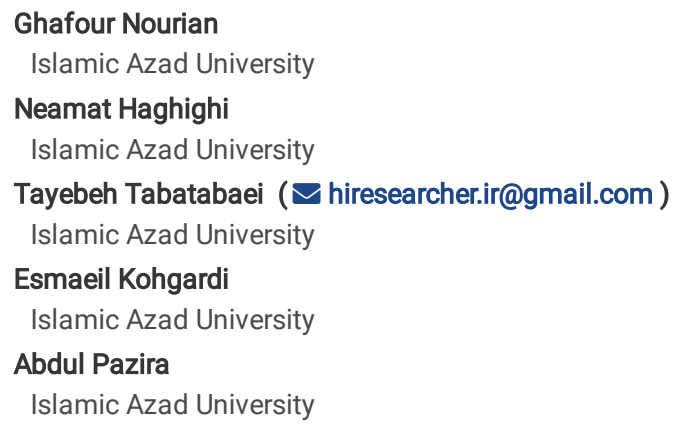




\section{Abstract}

A total 20 sediment and 20 Indian halibut samples were sampled from Asaluyeh, Kangan, Khark, Emam Hasan and Bushehr coast, Bushehr province, Iran for studying distribution and health risk assessment of polycyclic aromatic hydrocarbons (PAHs). PAHs were analyzed using HPLC. The mean $₫$ PAHs concentrations in sediment and Indian halibut samples were $6.894 \pm 1.4301$ and $14.807 \pm 7.486 \mathrm{mg} / \mathrm{kg}$, respectively. There was a significant positive relationship $(\mathrm{P}<0.05)$ between $\triangle \mathrm{PAHs}, 2-3$ ring compounds, and 4 ring compounds in the sediments and Indian halibut samples. $\triangle \mathrm{PAHs}$ concentration in sediments and Indian halibuts was higher in Asaluyeh area followed by Khark area. The values of PAHs pollution in the Bushehr province coastline were low to very high. The toxic equivalent quotient (TEQ), excess cancer risk (ECR), and the incremental lifetime cancer risk (ILCR) were applied for health risk assessment. Based on TEQ calculation, DA was a good marker in assessing PAHs related to health risk. DDI values for $\sum$ PAHs and $\sum$ CPAHs (carcinogenic PAHs) were also highest in Asaluyeh and Kangan, respectively. ILCR values for sediments in $10 \%$ of all stations and cumulative ECR values for Indian halibuts in all studied areas exceeded the USEPA acceptable level thus suggesting a potential cancer risk. Thus, regular monitoring of PAHs pollutants in the coastlines of Bushehr province is recommended.

\section{Introduction}

PAHs are resistant organic compositions by two or further benzene rings made of carbon and hydrogen (Gu et al. 2017; Lasota et al. 2021; Li et al. 2019). They are divided into light molecular weight (LMW) and heavy molecular weight (HMW) compounds. LMWs have two to three rings, while HMWs have five and more rings (Adeniji et al. 2019; Keshavarzifard et al. 2017). The LMW compounds originate from oil and oil products (petrogenic source), while HMW compounds are derived from fossil and biomass at high temperature (pyrogenic source) (Le Ha 2016). PAHs, produced from natural and anthropogenic activities, are transported to marine environments through atmospheric deposition, domestic wastes, urban runoff, industrial wastewater, and sanitary sewage (Gencosman and Sanli 2021; Ghanavati et al. 2019; Ingrid et al. 2016; Kostecki and Kowalski 2019). In marine environments, PAHs can easily accumulate in suspended particulate matter, sediments, and finally in living organisms (Yang et al. 2019). Bioaccumulation and toxic effects of PAHs in aquatic and their transfer to humans are a major concern (Moslen et al. 2019). These compounds have mutagenic, hepatotoxic, teratogenic, and carcinogenic effects; thus, inhalation, ingestion, and dermal contact of PAHs are a serious health risk (Le Ha 2016; Pourfadakari et al. 2019). Large amounts of halibut samples are used daily in Bushehr Province; so, it is important to assess the exposure of people's meal to PAHs.

The coastline of Bushehr province is also a semi-closed area at the subtropical zone. This region has approximately $60 \%$ of the world's oil resources. Twothirds of the universal oil transit occurs in this region, which leads to the PAHs accumulation in sediments and aquatic organisms (Keshavarzifard et al. 2017; Mirza et al. 2014). Few studies are available about cancer risk evaluation due to PAHs in the coastal sediments and Indian halibut of the Bushehr Province.

The aims of this study were to determine the levels from the 16 priority PAHs at surface sediments and Indian halibuts of Bushehr Province and to assess the possible level of health risk for humans using ILCR and ECR models.

\section{Materials And Methods Study Area and Sampling}

Sediment and Indian halibut samples were randomly collected from 20 different stations along Bushehr Province coastline including Asaluyeh, Kangan, Khark, Emam Hasan, and Bushehr, throughout January 2019 and February 2019 (Fig. 1). The geographical locations of studied stations were registered by GPS. Sediments were collected from surface sediment $(0-5 \mathrm{~cm})$ by a clean spatula. Samples of sediment and Indian halibut were immediately covered in an aluminum foil and removed on ice to the laboratory. They were freeze-dried, sieved, with the fractions under $2 \mathrm{~mm}$ saved at $-20 \circ \mathrm{C}$ for subsequent analysis.

\section{Chemical Analysis}

Extraction of PAHs from sediment samples was carried out according to the following procedure: $250 \mathrm{ml}$ dichloromethane - $\mathrm{n}$-hexane (1:1) was added to $10 \mathrm{~g}$ of each freeze-dried sediment and then the mixture was placed in soxhlet for 8 hours. The residual was condensed to $15 \mathrm{ml}$ by a rotary evaporator. Active copper (2-3 g) was added to the residual for eliminating sulfur, and so the mixture was filtered to 24 hours. The residual was passed from a column comprising $10 \mathrm{~g}$ silica, $10 \mathrm{~g}$ active alumina, and $2 \mathrm{~g}$ anhydrous sodium sulfate. The mixture was concentrated to $5 \mathrm{ml}$ again and was placed in scaled vials. Once the solvent was evaporated completely, $1 \mathrm{ml}$ acetonitrile was added to the sample for HPLC injection (Moopam 1999).

Specifically, $5 \mathrm{~g}$ of the dried edible part of Indian halibut was carefully mixed with $5 \mathrm{ml} \mathrm{KOH} \mathrm{(50 \% ),} 75 \mathrm{ml}$ methanol, $1 \mathrm{ml}$ internal standard solution. This mixture was placed in soxhlet for 4 hours. After transferring the liquid phase to the separator funnel, $100 \mathrm{ml}$-hexane was added and vigorously shaken to 3 min. The methanol- $\mathrm{KOH}$ solution was evacuated and then hexane phase was also washed with $50 \mathrm{ml}$ methanol-water solution (8:1) and $50 \mathrm{ml}$ water. The methanol-water and water solutions were evacuated. The organic phase from extraction stages was collected and concentrated by rotary evaporator. The samples were passed from the column containing $15 \mathrm{~g}$ silica, $10 \mathrm{~g}$ active alumina, and $1 \mathrm{~g}$ anhydrous sodium sulfate. The mixture was condensed in the rotary evaporator. After complete evaporation of the solvent, and dissolution of $1 \mathrm{~mL}$ acetonitrile, the samples were injected into an HPLC (Basak et al., 2010).

The PAHs were measured using the HPLC device equipped with a fluorescence and UV detector and reversed-phase of C18 column. The movable phase was acetonitrile $60 \%$ and water $40 \%$, which was changed to $100 \%$ acetonitrile after $27 \mathrm{~min}$.

The standard solutions used for the calibration of HPLC were decachlorobiphenyl and standard PAH compounds from Merck. PAHs standard composition included 16 different aromatic compounds: Acenaphthylene, Naphthalene, Acenaphthene, Phenanthrene, Anthracene, Fluoranthene, Fluorene, Pyrene, 
Chrysene, Benzo(b)fluoranthene, Benzo(k)fluoranthene, Benzo(a)anthracene, Benzo[a]pyrene, Indeno(1,2,3,cd)pyrene, Benzo(g.h.i)perylene,

Dibenz[a,h]anthracene.

\section{Risk Assessment}

The dietary daily intake (DDI) values of PAHs via Indian halibut eating were assessed for adults with an average weight (70 Kg) using Eq. (1) (Tongo et al. 2017).

$\mathrm{DDI}(\mathrm{mg} /$ day $)=\mathrm{Ci} \times \mathrm{IFR}$

The toxicity and carcinogenic ability of the high molecular weight PAHs compared to BaP were determined by toxic equivalent quotient (TEQ). This quotient is related to the valence of any congener for create modification in DNA of human. The BaP carcinogenic equivalent (TEQ) for the individual PAHs in sediment and fish samples was calculated by Eq. (2) (Le Ha, 2016).

$\mathrm{TEQ}=\mathbb{Q}(\mathrm{TEFn} * \mathrm{Ci})$

Where $\mathrm{Ci}=$ concentration of the individual PAHs in the sampling sediments and Indian halibuts $(\mathrm{mg} / \mathrm{kg} \mathrm{dw})$, and TEFn = toxic equivalence factor for individual PAHs.

The incremental lifetime cancer risk (ILCR) evaluates exposure health risk from PAHs according to USEPA standard. The major pathways for human exposure to sediments PAHs are include (a) inhalation, (b) ingestion, and (c) dermal contact, with the age categories of children (1-11 years) and adults (18-70 years). The following equations $(3,4,5)$ were applied to evaluate the incremental lifetime cancer risk (ILCR) from PAHs in the sediments (Pongpiachan 2016).

$$
\begin{aligned}
& \operatorname{ILCR}(\text { Ingestion })=\frac{\sum T E Q \cdot\left\{C S F_{\text {ingestion }}(B W / 70)^{\frac{1}{3}}\right\} \cdot E D, E F \cdot I R_{\text {ingestion }}}{B W, A T \cdot 10^{6}} \\
& \operatorname{ILCR}_{(\text {Inhalation })}=\frac{\sum T E Q \cdot\left\{C F_{\text {inhalatation }}(B W / 70)^{\frac{1}{3}}\right\}, E D, E F, I R_{\text {inhalation }}}{B W \cdot A T, B E F} \\
& \operatorname{ILCR}(\text { Dermal contact })=\frac{\sum \tau E Q,\left\{C S F_{\text {Dermal contact }}(B W / 70)^{\frac{1}{3}}\right\}, A B S, A F, S A, E F, E D}{B W, A T \cdot 10^{6}}
\end{aligned}
$$

The excess cancer risk of PAHs from Indian halibut consumption was calculated using Eq. (6) (Tongo et al. 2017).

Excess Cancer Risk (ECR) $=\Sigma Q * B(A)$ Pteq * IFR * ED / (BW * ATn)

Human risk model parameters in the sediment and Indian halibut samples are presented in Tables1 and 2, respectively.

\section{Analysis of Data}

The SPSS-23 software was applied to the statistical analyses of results. The results were presented as the average \pm standard deviation (SD). The correlation between data was tested with Pearson's correlation coefficient and analysis of variance (ANOVA). The level of $P<0.05$ was significant.

\section{Results}

\section{Distribution Pattern of PAHs}

PAHs concentrations evaluated in the coastal sediment and Indian halibut samples of Bushehr province have been summarized in Table 3. The individual PAHs were distributed in various stations with different patterns. Acenaphthene and naphthalene had the highest average concentration of $2.275 \pm$ $4.993 \mathrm{mg} / \mathrm{kg} \mathrm{dw}$ and $3.906 \pm 3.039 \mathrm{mg} / \mathrm{kg} \mathrm{dw}$ at the sediment and Indian halibut samples, respectively. The least mean values in the sediment and Indian halibut samples were recorded by Benzo(ghi)perylene and Benzo(b)flouranthene.

Mean total PAHs concentrations in the sediment samples of Asaluyeh, Kangan, Khark, Emam Hasan, and Bushehr stations averaged 14.267, 2.777, 13.562, 3.865 and ND mg/kg, respectively (Fig 2). The means of total PAHs concentrations in the edible part of Indian halibuts of Asaluyeh, Kangan, Khark, Emam Hasan, and Bushehr stations were 22.999, 13.400, 20.977, 12.400 and 4.260mg/kg dw, respectively (Fig. 2). The $\otimes P A H$ concentration was highest at Asaluyeh area, but was not significantly difference $(p>0.05)$ among the samples of PAHs.

A considerable positive relationship was found between the total PAHs concentration with compounds 2-3 rings, and 4 rings in the sediments and the edible part of Indian halibuts in the studied stations (Fig. 3).

\section{Risk Assessments}

The carcinogenic potential of the eight compounds of PAHs generally noted as possible human carcinogens have been reported in Table 3. The results showed that BaP carcinogenic equivalent (TEQ) in sediment and Indian halibut samples varied from $0 \mathrm{mg} / \mathrm{kg}$ to $7.999 \mathrm{mg} / \mathrm{kg}$ with a medium concentration of 
$0.804 \pm 2.338 \mathrm{mg} / \mathrm{kg}$ and $0.290 \mathrm{mg} / \mathrm{kg}$ to $3.562 \mathrm{mg} / \mathrm{kg}$ with an average concentration of $1.673 \pm 1.545 \mathrm{mg} / \mathrm{kg}$, respectively.

The Indian halibut is consumed in Bushehr province; therefore, it is necessary to calculate dietary daily intake (DDI) of PAHs due to Indian halibut consumption for human health risk evaluation. The DDI amounts of individual PAHs at Indian halibuts for an adult population are summarized in Table 5. These values were obtained from 0-0.355 (Asaluyeh), 0-0.195 (Kangan), 0-0.336 (Khark), 0-0.368 (Emam Hasan), and 0-0.164 (Bushehr). Based on the ANOVA analysis, differences in DDI values of PAHs between studied areas were not significant $(p>0.05, F=1.61)$.

The calculated DDI values for $\triangle \mathrm{PAHs}$ in Indian halibut samples were1.371, 0.787, 1.194, 0.678, and 0.233 (mg/kg) for Asaluyeh, Kangan, Khark, Emam Hasan and Bushehr areas, respectively. On the other hand, the DDI values for $₫ \mathrm{CPAHs}$ were $0.276,0.461,0.196,0.175$, and 0.223 (mg/kg) for Asaluyeh, Kangan, Khark, Emam Hasan and Bushehr areas, respectively (Table5). DDI values for $\sum$ PAHs and $\sum$ CPAHs were highest in Asaluyeh and Kangan, respectively.

This study has determined the potential carcinogenic risk caused by the exposure of human with PAHs in surface sediment and Indian halibut samples. The potential cancer risk values of PAHs in sediments for adults and children have been summarized in Table 4. The results showed that both ILCRDermal and ILCRIngestion were significantly higher than ILCRInhalation.

The excess cancer risk (ECR) in adults exposed to PAHs from Indian halibut consumption was also investigated. The ECR values in different areas are presented in Table 5. These values were compared with the receivable instructions value of USEPA.

\section{Discussion}

\section{Distribution Pattern of PAHs}

As observed in Table 3, the individual PAHs were distributed in various stations with different patterns. This difference in distribution of PAHs compounds may be a function of the amount and the nature of inputs in each station. In addition, factors such as organic carbon content, structure, diameter of sediment particles, and water solubility are effective in the distribution and abundance from PAHs at sediments and Indian halibut (Nikpour and Ghanemi 2012).

According to Fig. 2, concentration of PHAs is high in studied regions. The high PAHs concentrations in these areas can possibly be because of proximity of sampling stations to gas refineries and discharge of refinery sewage as well as urban sewage into the marine ecosystem. On the Khark Island, a great volume of oil is also loaded daily to export; thus, large amount of PAHs are imported into the sea due to oil spills and leakages. The lowest PAHs concentration was detected at Bushehr stations. Being away from ports and municipal areas and the absence of direct discharges may be the main reasons for these stations remaining cleaner than others.

Furthermore, concentrations of PAHs in the edible part of fishes are higher than in the sediments, suggesting the ability of PAHs accumulation by the fishes. Due to the presence of fat at tissue of living organisms, the pollutants are absorbed effectively in their tissues. On the other hand, hydrocarbon pollutants present in the sediments are decomposed in various ways such as optical photosynthesis and microbial processes (Ingrid et al. 2016; Partila 2013).

PAHs contaminants are classified in various groups comprising: low $(0-100 \mathrm{ng} / \mathrm{g})$, moderate $(100-1,000 \mathrm{ng} / \mathrm{g})$, high $(1,000-5,000 \mathrm{ng} / \mathrm{g})$, and very high $(>5,000 \mathrm{ng} / \mathrm{g}$ ) (Baumard et al. 1998). Accordingly, sediments from Asaluyeh and Khark coasts can be classified in very high group, Kangan and Emam Hasan shores can fall in the high group for PAHs contamination. Indian halibut samples in the all studied areas except the Bushehr coasts are classified in the very high group for PAHs contamination. The sediment and fish samples in Bushehr area can be categorized in low groups for PAHs contamination.

The concentration of tPAHs in the sediments and Indian halibuts of Bushehr Province coastal in this paper was compared to the prior studies across the world. According to these results, Bushehr province sediments are more contaminated by PAHs than the largest deep plateau lake in China (Gu et al. 2017) and Persian Gulf, Iran in Bushehr sediments (Nikpour and Ghanemi 2012), while is less contaminated by PAHs compared to Santander Bay in Northern Spain (Viguri et al. 2002) and Boston Port at the US (Wang et al. 2001). The Indian halibut samples had more PAHs contaminants than the bivalve in Port Harcourt (Moslen et al. 2019) and smoky fish forms in Nigeria (Tongo et al. 2017).

The correlation between total PAHs concentration with compounds 2-3 rings, and 4 rings suggests that the studied fishes can accumulate the sedimentary PAHs in their textures. 176 This is probably due to the lifestyle of the studied fish. These fishes are one of the most important fish near the 177 coasts. Thus, they are in close contact with sediments contaminated with PAHs (Yasemi et al. 2007).

\section{Risk Assessments}

According to Table 3 , in this study, CPAHs claimed approximately $19 \%$ and $40 \%$ of the $\triangle P A H s$ determined in the sediments and Indian halibuts, respectively. TEQ obtained for the eight PAHs showed that share of DA was exceptionally higher in the sediment and Indian halibut samples; our results are in line whit Adeniji (2019) and Moslen (2019) results (Adeniji et al. 2019; Moslen et al. 2019). This combination of PAHs accounted for approximately $93 \%$ and $83 \%$ of the total TEQ in the sediments and Indian halibuts, respectively (Fig. 4). Thus, the TEQ values obtained for DA in this study showed that this congener may create a higher probable cancer risk for those which might be exposed to sediments and Indian halibuts in studied coastal areas.

The results of DDI values for $\triangle \mathrm{PAH}$ in the present study demonstrate that Indian halibut consumption in Asalouyeh and Kangan leads to exposure to PAHs and CPAHs, respectively, thus endangering human health. Accordingly, regular monitoring of PAHs in the marine ecosystems of studied areas is recommended. 
As shown in Table 4, both ILCRDermal and ILCRIngestion were significantly higher than ILCRInhalation, suggesting that respiration of sediments PAHs through mouth and nose are less than through other exposure methods. The result was similar to the Pongpiachan study (Pongpiachan 2016). For both age groups, the ILCRDermal was higher $(p<0.05)$ than ILCRIngestion, suggesting that the dermal contact significantly contributed to the cancer risk. The findings were compatible with results of Mousavi (Mousavi et al. 2017).

According to instructions for carcinogen risk evaluation, ILCR values of $10^{-6}-10^{-4}$ indicate potential cancer risk, while the feasible safety was obtained with an ILCR value of $10^{-6}$ or less and an ILCR values higher than $10^{-4}$ (Liao and Chiang 2006). In this study, $90 \%$ of all stations had cancer risk values less than $10^{-6}$, indicating safety cancer risk. On the other hand, $10 \%$ of cancer risk values in all stations ranged within $10^{-6}-10^{-4}$, indicating potential cancer risk, thus warranting immediate attention.

Accordingly, if the level of ECR (age $\geq 70$ year) is equal to $10^{-6}$, the risk level is acceptable, but ECR equal to or greater than $10^{-4}$ has a serious risk. In the present research, the ECR values for every individual PAH except for DA were less than threshold value of USEPA (10-6) (Table 5), but the collective values of ECR in Indian halibut samples in all studied areas exceeded the USEPA acceptable level. Thus, consumption of Indian halibut could lead to a potential cancer risk.

\section{Conclusion}

The PAHs values in sediments and Indian halibut of Bushehr Province were low to very high. The extent of pollution due to sediment PAHs was highest in Asaluyeh, Khark, Emam Hasan, Kangan, and Bushehr, respectively, while this sequence in Indian halibut samples was as follows: Asaluyeh, Khark, Kangan,Emam Hasan, and Bushehr. Based on TEQ calculation, DA is a suitable maker in determining PAHs regarding health risk. The findings of the present paper indicate that consumption of Indian halibuts in Asalouyeh and Kangan leads to exposure to PAHs and CPAHs, respectively. The calculated ILCR due to the PAHs in sediments showed which ingestion and dermal contact exposure are dominant for adults and child with potential cancer risk from sediments present in $10 \%$ of all stations. The collective values of ECR in adults exposed to PAHs from Indian halibut consumption also indicated that excess cancer risk in all studied areas exceeded the USEPA acceptable level. Thus, PAHs regular monitoring at the studied ecosystems is recommended.

\section{Declarations}

\section{Conflict of interest}

Authors have no conflicts of interest to declare.

\section{Funding information}

This study has received no fund.

\section{Data availability}

Not applicable

\section{Author contribution}

G. N. Performed experiments and drafted the manuscript. N. J., T. T., E. K. and A. R. P. reviewed the manuscript. All authors contributed to the critical reading and discussion of the manuscript. All authors have read and agreed to the published version of the manuscript.

\section{Animal research}

Not applicable

\section{Consent to participate}

Not applicable

\section{Consent to publish in the manuscript}

Not applicable

\section{References}

1. Adeniji AO, Okoh O, Okoh A (2019) Distribution pattern and health risk assessment of polycyclic aromatic hydrocarbons in the water and sediment of Algoa Bay, South Africa. Environ Geochem Health 41:1303-1320

2. Baumard P, Budzinski H, Michon Q, Garrigues P, Burgeot T, Bellocq J (1998) Origin and bioavailability of PAHs in the Mediterranean Sea from mussel and sediment records. Estuar Coast Shelf Sci 47:77-90

3. Gencosman BC, Sanli GE (2021) Prediction of Polycyclic Aromatic Hydrocarbons (PAHs) Removal from Wastewater Treatment Sludge Using Machine Learning Methods. Water Air Soil Pollut 232:1-17 
4. Ghanavati N, Nazarpour A, Watts MJ (2019) Status, source, ecological and health risk assessment of toxic metals and polycyclic aromatic hydrocarbons (PAHs) in street dust of Abadan, Iran. Catena 177:246-259

5. Gu Y-G, Li H-B, Lu H-B (2017) Polycyclic aromatic hydrocarbons (PAHs) in surface sediments from the largest deep plateau lake in China: Occurrence, sources and biological risk. Ecol Eng 101:179-184

6. Ingrid L, Sahraoui AL-H, Frédéric L, Yolande D, Joël F (2016) Arbuscular mycorrhizal wheat inoculation promotes alkane and polycyclic aromatic hydrocarbon biodegradation: microcosm experiment on aged-contaminated soil. Environ Pollut 213:549-560

7. Keshavarzifard M, Moore F, Keshavarzi B, Sharifi R (2017) Polycyclic aromatic hydrocarbons (PAHs) in sediment and sea urchin (Echinometra mathaei) from the intertidal ecosystem of the northern Persian Gulf: Distribution, sources, and bioavailability. Mar Pollut Bull 123:373-380

8. Kostecki M, Kowalski E (2019) Polycyclic Aromatic Hydrocarbons in Bottom Sediments of Selected Anthropogenic Reservoirs in Terms of Catchment Area Development. Water Air Soil Pollut 230:1-11

9. Lasota J, Łyszczarz S, Kempf P, Kempf M, Błońska E (2021) Effect of Species Composition on Polycyclic Aromatic Hydrocarbon (PAH) Accumulation in Urban Forest Soils of Krakow. Water Air Soil Pollut 232:1-12

10. Le Ha VT (2016) Human health hazard of polycyclic aromatic hydrocarbon in road dust in Ha Noi metropolis Vietnam. J Agric Sci Technol 54:27

11. Li R, Hua P, Zhang J, Krebs P (2019) A decline in the concentration of PAHs in Elbe River suspended sediments in response to a source change. Sci Total Environ 663:438-446

12. Liao C-M, Chiang K-C (2006) Probabilistic risk assessment for personal exposure to carcinogenic polycyclic aromatic hydrocarbons in Taiwanese temples. Chemosphere 63:1610-1619

13. Mirza R, Mohammadi M, Faghiri I, Abedi E, Fakhri A, Azimi A, Zahed MA (2014) Source identification of polycyclic aromatic hydrocarbons (PAHs) in sediment samples from the northern part of the Persian Gulf, Iran. Environ Monit Assess 186:7387-7398

14. Moopam A (1999) Manual of oceanographic observation and pollution analysis. regional or-ganization for the protection of Marine Environment (ROPME)

15. Moslen M, Miebaka C, Boisa N (2019) Bioaccumulation of Polycyclic Aromatic Hydrocarbon (PAH) in a bivalve (Arca senilis-blood cockles) and health risk assessment. Toxicol Rep 6:990-997

16. Mousavi S, Shakeri A, Nakhaei M (2017) Contamination, source apportionment and health risk assessment of Polycyclic Aromatic Hydrocarbons (PAHs) in soils of Bandar Abbas county central district Iranian. J Environ Public Health 10:271-280

17. Nikpour Y, Ghanemi K (2012) Distribution and sources of polycyclic aromatic hydrocarbons in the sediment of Bushehr coastal zone-Iran. IJEE 3:173-179

18. Partila AM (2013) Biodegradation Of Polycyclic Aromatic Hydrocarbons In Petroleum Oil Contaminating The Environment.

19. Pongpiachan S (2016) Incremental lifetime cancer risk of PM2. 5 bound polycyclic aromatic hydrocarbons (PAHs) before and after the wildland fire episode. Aerosol Air Qual Res 16:2907-2919

20. Pourfadakari S, Ahmadi M, Jaafarzadeh N, Takdastan A, Ghafari S, Jorfi S (2019) Remediation of PAHs contaminated soil using a sequence of soil washing with biosurfactant produced by Pseudomonas aeruginosa strain PF2 and electrokinetic oxidation of desorbed solution, effect of electrode modification with Fe304 nanoparticles. J Hazard Mater 379:120839

21. Tongo I, Ogbeide O, Ezemonye L (2017) Human health risk assessment of polycyclic aromatic hydrocarbons (PAHs) in smoked fish species from markets in Southern Nigeria. Toxicol Rep 4:55-61

22. Viguri J, Verde J, Irabien A (2002) Environmental assessment of polycyclic aromatic hydrocarbons (PAHs) in surface sediments of the Santander Bay, Northern Spain. Chemosphere 48:157-165

23. Wang X-C, Zhang Y-X, Chen RF (2001) Distribution and partitioning of polycyclic aromatic hydrocarbons (PAHs) in different size fractions in sediments from Boston Harbor, United States. Mar Pollut Bull 42:1139-1149

24. Yang T et al. (2019) Comparative study of polycyclic aromatic hydrocarbons (PAHs) and heavy metals (HMs) in corals, surrounding sediments and surface water at the Dazhou Island, China. Chemosphere 218:157-168

25. Yasemi M, Keyvan A, Vosough GH, Ahmadi MR, Farzin GM, Fatemi M, Mahianeh A (2007) Identification of the species of pleurone ctiformes order inhabiting in the Persian Gulf coastline area Bushehr provience regarding morphometrics and meristics characteristics (parameters).

\section{Tables}

Table 1 Health risk model components at the sediment samples 


\begin{tabular}{|c|c|c|c|}
\hline Components & Unit & Value & \\
\hline Carcinogenic slope factor for ingestion ( $\left.\mathrm{CSF}_{\text {Ingestion }}\right)$ & $\mathrm{mg} \mathrm{kg}^{-1}$ day $^{-1}$ & 7.3 & \\
\hline Carcinogenic slope factor for dermal ( CSF $\left._{\text {Dermal }}\right)$ & $\mathrm{mg} \mathrm{kg}^{-1}$ day $^{-1}$ & 25 & \\
\hline Carcinogenic slope factor for inhalation $\left(\mathrm{CSF}_{\text {Inhalation }}\right)$ & $\mathrm{mg} \mathrm{kg}^{-1}$ day $^{-1}$ & 3.85 & \\
\hline \multirow[t]{2}{*}{ Body weight (BW) } & $\mathrm{Kg}$ & Child: 15 & adult: \\
\hline & & 61.5 & \\
\hline Exposure frequency of the (EF) & $\mathrm{d} \mathrm{a}^{-1}$ & 180 & \\
\hline Exposure duration (ED) & Years & Child: 6 & adult: 24 \\
\hline Inhalation rate $\left(\mathrm{IR}_{\operatorname{Inhalation}}\right)$ & $\mathrm{m}^{3}$ day $^{-1}$ & Child: 10 & adult: 20 \\
\hline \multirow[t]{2}{*}{ Dust ingestion rate $\left(\mathrm{I}_{\text {Ingestion }}\right)$} & $\mathrm{mg} \mathrm{day}^{-1}$ & Child: 200 & adult: \\
\hline & & 100 & \\
\hline \multirow[t]{2}{*}{ Dermal exposure area (SA) } & $\mathrm{cm}^{2}$ & Child: 2800 & adult: \\
\hline & & 5700 & \\
\hline \multirow[t]{2}{*}{ Dermal adherence factor (AF) } & $\mathrm{mg} \mathrm{cm}^{-2}$ & Child: 0.2 & adult: \\
\hline & & 0.07 & \\
\hline Dermal adsorption fraction (ABS) & & 0.13 & \\
\hline Averaging life span (AT) & Dayes & 25,550 & \\
\hline Particle emission factor (PEF) & $\mathrm{m}^{3} \mathrm{~kg}-1$ & $1.36 \times 10^{9}$ & \\
\hline
\end{tabular}

Table 2 Health risk model parameters in the Indian halibut samples

\begin{tabular}{|lll|}
\hline Parameters & Unit & Value \\
\hline Concentration of each congener (Ci) & $\mathrm{mg} / \mathrm{kg}$ & - \\
\hline Fish ingestion rate (IFR) & $\mathrm{kg} / \mathrm{capita} / \mathrm{day}$ & 0.0548 \\
\hline Carcinogenic potency of Benzo[a]Pyrene (Q) & $\mathrm{mg} / \mathrm{kg} / \mathrm{d}$ & 7.3 \\
\hline Exposure Duration (ED) & years & 30 \\
\hline Adult body weight (BW) & $\mathrm{kg}$ & 70 \\
\hline Average lifespan (ATn) & days & 8760 \\
\hline
\end{tabular}

Table 3 PAHs concentrations evaluated in the coastal sediments and Indian halibuts of Bushehr province 


\begin{tabular}{|c|c|c|c|c|c|c|}
\hline \multirow[t]{2}{*}{ Compounds } & \multicolumn{3}{|c|}{ Sediments } & \multicolumn{3}{|c|}{ Indian halibuts } \\
\hline & TEF & Mean (mg/kg dw) & Std.De & TEF & Mean (mg/kg dw) & Std.De \\
\hline Naphthalene (Nap) & - & 0.518 & 1.598 & 0.001 & 3.906 & 3.039 \\
\hline Acenaphthylene (Acy) & - & 1.705 & 4.291 & 0.001 & 2.282 & 3.139 \\
\hline Acenaphthene (Ace) & - & 2.275 & 4.993 & 0.001 & 1.224 & 1.471 \\
\hline Flourene (FI) & - & 0.334 & 0.624 & 0.001 & 1.074 & 0.909 \\
\hline Phenanthrene (Phe) & - & 0.006 & 0.016 & 0.001 & 0.052 & 0.053 \\
\hline Anthracene (Ant) & - & 0.435 & 0.997 & 0.01 & 0.532 & 0.832 \\
\hline Flouranthene (Flu) & - & 0.005 & 0.015 & 0.001 & 0.270 & 0.603 \\
\hline Pyrene (Pyr) & - & 0.309 & 0.924 & 0.001 & 1.034 & 0.969 \\
\hline Benzo(a) anthracene (BaA) & 0.1 & 0.011 & 0.029 & 0.1 & 0.122 & 0.167 \\
\hline Chrysene (Chry) & 0.001 & 0.013 & 0.034 & 0.01 & 0.066 & 0.121 \\
\hline Benzo(b)flouranthene (BbF) & 0.1 & ND & 00.00 & 1 & 0.040 & 0.055 \\
\hline Benzo(k)flourathene (BkF) & 0.01 & 0.036 & 0.060 & 0.1 & 0.178 & 0.245 \\
\hline Benzo(a) pyrene (BaP) & 1 & 0.004 & 0.012 & 0.1 & 0.054 & 0.099 \\
\hline Dibezo(ah) anthracene (DbA) & 1 & 0.751 & 2.242 & 1 & 1.388 & 1.538 \\
\hline Benzo(ghi) perylene (BgP) & - & ND & 00.00 & 0.01 & 0.530 & 1.005 \\
\hline Indeno (1,2,3-cd) pyrene (IdP) & 0.1 & 0.482 & 1.032 & 0.1 & 2.044 & 1.426 \\
\hline बPAHs & - & 6.894 & 1.4301 & - & 14.796 & 7.476 \\
\hline$\triangle T E Q$ & - & 0.804 & 2.338 & - & 1.692 & 1.533 \\
\hline
\end{tabular}

ND: Not Detection

Table 4 Potential cancer risk values of PAHs in sediments for children and adults 


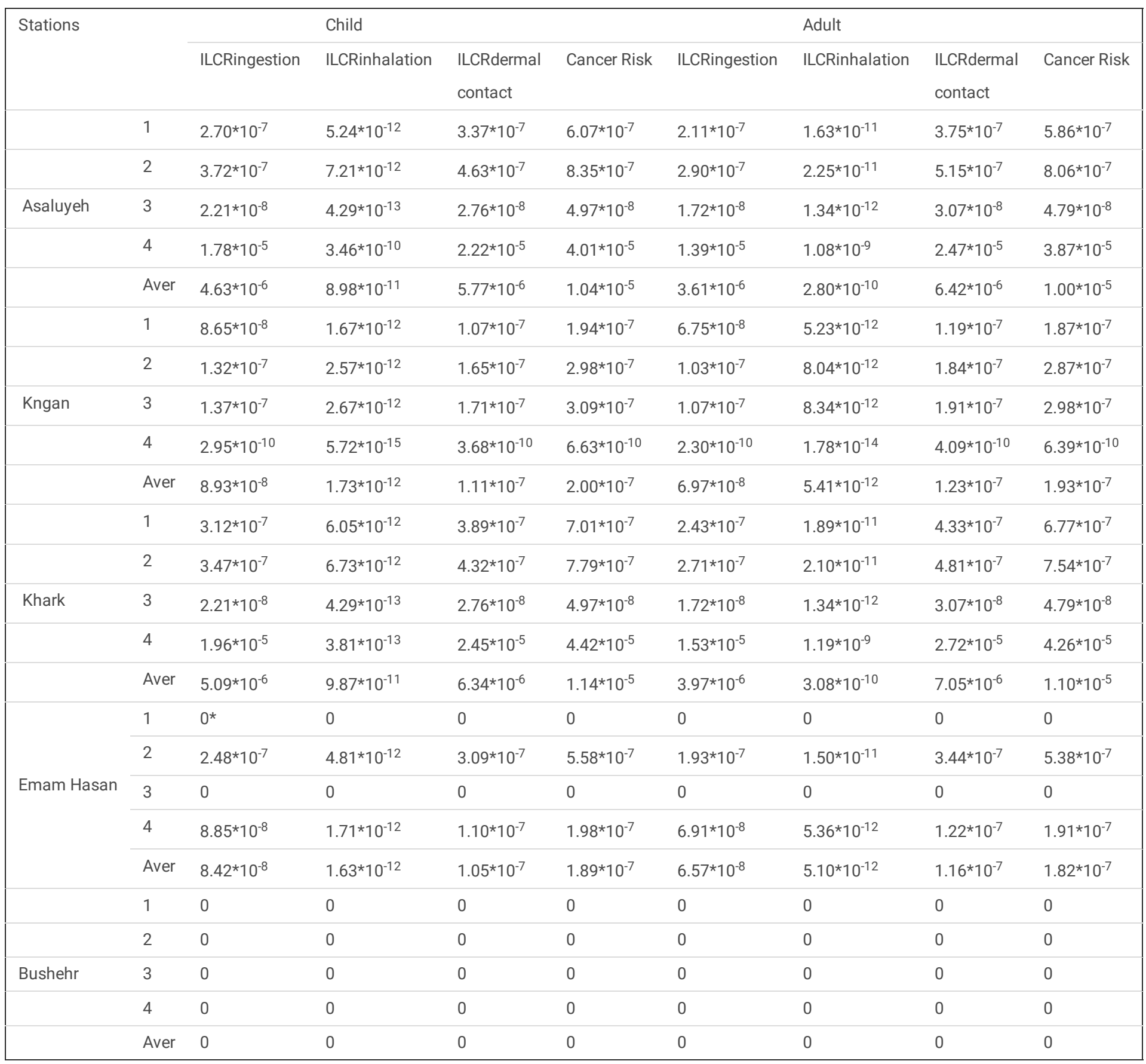

*: Not Detection

Table 5 Concentration (Ci), Dietary daily intake (DDI), Carcinogenic potencies (B(A)Pteq), and Excess cancer risk (ECR) of PAHs in Indian halibut samples 


\begin{tabular}{|c|c|c|c|c|c|c|c|c|c|c|c|c|c|c|c|c|}
\hline \multirow[t]{2}{*}{$\begin{array}{l}\text { PAH } \\
s\end{array}$} & \multicolumn{5}{|c|}{$\begin{array}{l}\text { Concentration }(\mathrm{Ci}) \\
(\mathrm{mg} / \mathrm{kg})\end{array}$} & \multicolumn{5}{|c|}{ DDI } & \multicolumn{6}{|c|}{$\mathrm{B}(\mathrm{A})$ Pteq } \\
\hline & A & $\mathrm{K}$ & $\mathrm{Kh}$ & $\mathrm{EH}$ & B & $A$ & $\mathrm{~K}$ & $\mathrm{Kh}$ & $\mathrm{EH}$ & B & A & $\mathrm{K}$ & $\mathrm{Kh}$ & $\mathrm{EH}$ & B & $A$ \\
\hline $\mathrm{NaP}$ & 6.48 & 1.43 & 4.89 & 6.73 & ND & $\begin{array}{l}3.55 \mathrm{E}- \\
01\end{array}$ & $\begin{array}{l}7.84^{\star} \mathrm{E}- \\
02\end{array}$ & $\begin{array}{l}2.67 \mathrm{E}- \\
01\end{array}$ & $\begin{array}{l}3.68 \mathrm{E}- \\
01\end{array}$ & 0 & $\begin{array}{l}6.48 \mathrm{E}- \\
03\end{array}$ & $\begin{array}{l}1.43 \mathrm{E}- \\
03\end{array}$ & 4.89E-03 & $\begin{array}{l}6.73 \mathrm{E}- \\
03\end{array}$ & 0 & $\begin{array}{l}1.2 \\
07\end{array}$ \\
\hline Acy & 5.27 & ND & 6.14 & ND & ND & $\begin{array}{l}2.88 \mathrm{E}- \\
01\end{array}$ & 0 & $\begin{array}{l}3.36 \mathrm{E}- \\
01\end{array}$ & 0 & 0 & $\begin{array}{l}5.27 \mathrm{E}- \\
03\end{array}$ & 0 & $6.14 \mathrm{E}-03$ & 0 & 0 & $\begin{array}{l}1.6 \\
07\end{array}$ \\
\hline Ace & 1.60 & 3.56 & 0.96 & ND & ND & $\begin{array}{l}8.79 \mathrm{E}- \\
02\end{array}$ & $\begin{array}{l}1.95 \mathrm{E}- \\
01\end{array}$ & $\begin{array}{l}5.26 \mathrm{E}- \\
02\end{array}$ & 0 & 0 & $\begin{array}{l}1.60 \mathrm{E}- \\
03\end{array}$ & $\begin{array}{l}3.56 \mathrm{E}- \\
03\end{array}$ & $9.60 \mathrm{E}-04$ & 0 & 0 & $\begin{array}{l}3.1 \\
08\end{array}$ \\
\hline $\mathrm{FL}$ & 1.32 & 0.48 & 2.39 & 1.18 & ND & $\begin{array}{l}7.23 \mathrm{E}- \\
02\end{array}$ & $\begin{array}{l}2.63 \mathrm{E}- \\
02\end{array}$ & $\begin{array}{l}1.31 \mathrm{E}- \\
01\end{array}$ & $\begin{array}{l}6.46 \mathrm{E}- \\
02\end{array}$ & 0 & $\begin{array}{l}1.32 \mathrm{E}- \\
03\end{array}$ & $\begin{array}{l}4.80 \mathrm{E}- \\
04\end{array}$ & 2.39E-03 & $\begin{array}{l}1.18 \mathrm{E}- \\
03\end{array}$ & 0 & $\begin{array}{l}2.5 \\
08\end{array}$ \\
\hline Phe & 0.09 & ND & 0.05 & 0.12 & ND & $\begin{array}{l}4.93 \mathrm{E}- \\
02\end{array}$ & 0 & $\begin{array}{l}2.74 \mathrm{E}- \\
03\end{array}$ & $\begin{array}{l}6.57 \mathrm{E}- \\
03\end{array}$ & 0 & $\begin{array}{l}9.00 \mathrm{E}- \\
05\end{array}$ & 0 & $5.00 \mathrm{E}-05$ & $\begin{array}{l}1.20 \mathrm{E}- \\
04\end{array}$ & 0 & $\begin{array}{l}1.7 \\
09\end{array}$ \\
\hline Ant & 1.98 & 0.21 & ND & 0.47 & ND & $\begin{array}{l}1.08 \mathrm{E}- \\
01\end{array}$ & $\begin{array}{l}1.15 \mathrm{E}- \\
02\end{array}$ & 0 & $\begin{array}{l}2.57 \mathrm{E}- \\
02\end{array}$ & 0 & $\begin{array}{l}1.98 \mathrm{E}- \\
02\end{array}$ & $\begin{array}{l}2.10 \mathrm{E}- \\
03\end{array}$ & 0 & $\begin{array}{l}4.70 \mathrm{E}- \\
03\end{array}$ & 0 & $\begin{array}{l}3 . \varepsilon \\
07\end{array}$ \\
\hline Flu & ND & ND & 1.35 & ND & ND & 0 & 0 & $\begin{array}{l}7.39 \mathrm{E}- \\
02\end{array}$ & 0 & 0 & 0 & 0 & 1.35E-03 & 0 & 0 & 0 \\
\hline Pyr & 2.45 & 0.27 & 1.59 & 0.69 & 0.17 & $\begin{array}{l}1.34 \mathrm{E}- \\
01\end{array}$ & $\begin{array}{l}1.47 \mathrm{E}- \\
02\end{array}$ & $\begin{array}{l}8.76 \mathrm{E}- \\
02\end{array}$ & $\begin{array}{l}3.78 \mathrm{E}- \\
02\end{array}$ & $\begin{array}{l}9.31 \mathrm{E}- \\
03\end{array}$ & $\begin{array}{l}2.45 \mathrm{E}- \\
03\end{array}$ & $\begin{array}{l}2.70 \mathrm{E}- \\
04\end{array}$ & $1.59 \mathrm{E}-03$ & $\begin{array}{l}6.90 \mathrm{E}- \\
04\end{array}$ & $\begin{array}{l}1.70 \mathrm{E}- \\
04\end{array}$ & $\begin{array}{l}4 . \varepsilon \\
08\end{array}$ \\
\hline $\mathrm{BaA}$ & ND & 0.32 & 0.29 & ND & ND & 0 & $\begin{array}{l}1.75 \mathrm{E}- \\
02\end{array}$ & $\begin{array}{l}1.58 \mathrm{E}- \\
02\end{array}$ & 0 & 0 & 0 & $\begin{array}{l}3.20 \mathrm{E}- \\
02\end{array}$ & 2.90E-02 & 0 & 0 & 0 \\
\hline Chr & 0.05 & 0.28 & ND & ND & ND & $\begin{array}{l}2.74 \mathrm{E}- \\
02\end{array}$ & $\begin{array}{l}1.53 \mathrm{E}- \\
02\end{array}$ & 0 & 0 & 0 & $\begin{array}{l}5.00 \mathrm{E}- \\
04\end{array}$ & $\begin{array}{l}2.80 \mathrm{E}- \\
03\end{array}$ & 0 & 0 & 0 & $\begin{array}{l}9.7 \\
09\end{array}$ \\
\hline $\mathrm{BbF}$ & 0.09 & 0.11 & ND & ND & ND & $\begin{array}{l}4.93 \mathrm{E}- \\
02\end{array}$ & $\begin{array}{l}6.02 \mathrm{E}- \\
02\end{array}$ & 0 & 0 & 0 & $\begin{array}{l}9.00 \mathrm{E}- \\
02\end{array}$ & $\begin{array}{l}1.10 \mathrm{E}- \\
01\end{array}$ & 0 & 0 & 0 & $\begin{array}{l}1.7 \\
06\end{array}$ \\
\hline $\mathrm{BkF}$ & 0.57 & 0.27 & 0.05 & ND & ND & $\begin{array}{l}3.12 \mathrm{E}- \\
02\end{array}$ & $\begin{array}{l}1.47 \mathrm{E}- \\
02\end{array}$ & $\begin{array}{l}2.74 \mathrm{E}- \\
03\end{array}$ & 0 & 0 & $\begin{array}{l}5.57 \mathrm{E}- \\
02\end{array}$ & 2.70E-2 & 5.00E-03 & 0 & 0 & $\begin{array}{l}1.1 \\
06\end{array}$ \\
\hline $\mathrm{BaP}$ & ND & 0.23 & 0.04 & ND & ND & 0 & $\begin{array}{l}1.26 \mathrm{E}- \\
02\end{array}$ & $\begin{array}{l}2.19 \mathrm{E}- \\
03\end{array}$ & 0 & 0 & 0 & $\begin{array}{l}2.30 \mathrm{E}- \\
02\end{array}$ & 4.00E-03 & 0 & 0 & 0 \\
\hline $\mathrm{DbA}$ & ND & 3.05 & 0.89 & ND & 3.00 & 0 & $\begin{array}{l}1.67 \mathrm{E}- \\
01\end{array}$ & $\begin{array}{l}4.90 \mathrm{E}- \\
02\end{array}$ & 0 & $\begin{array}{l}1.64 \mathrm{E}- \\
01\end{array}$ & 0 & 3.05E00 & 8.90E0-1 & 0 & 3.00E00 & 0 \\
\hline $\mathrm{BgP}$ & ND & ND & 2.31 & 0.34 & ND & 0 & 0 & $\begin{array}{l}1.27 \mathrm{E}- \\
01\end{array}$ & $\begin{array}{l}1.86 \mathrm{E}- \\
02^{-}\end{array}$ & 0 & 0 & 0 & 2.31E-02 & $\begin{array}{l}3.40 \mathrm{E}- \\
03\end{array}$ & 0 & 0 \\
\hline IdP & 3.08 & 3.18 & ND & 2.87 & 1.09 & $\begin{array}{l}1.69 \mathrm{E}- \\
01\end{array}$ & $\begin{array}{l}1.74 \mathrm{E}- \\
01\end{array}$ & 0 & $\begin{array}{l}1.57 \mathrm{E}- \\
01\end{array}$ & $\begin{array}{l}5.97 \mathrm{E}- \\
02\end{array}$ & $\begin{array}{l}3.08 \mathrm{E}- \\
01\end{array}$ & $\begin{array}{l}3.18 \mathrm{E}- \\
01\end{array}$ & 0 & $\begin{array}{l}2.87 \mathrm{E}- \\
01\end{array}$ & $\begin{array}{l}1.09 \mathrm{E}- \\
01\end{array}$ & $\begin{array}{l}6 . c \\
06\end{array}$ \\
\hline
\end{tabular}

\section{Figures}



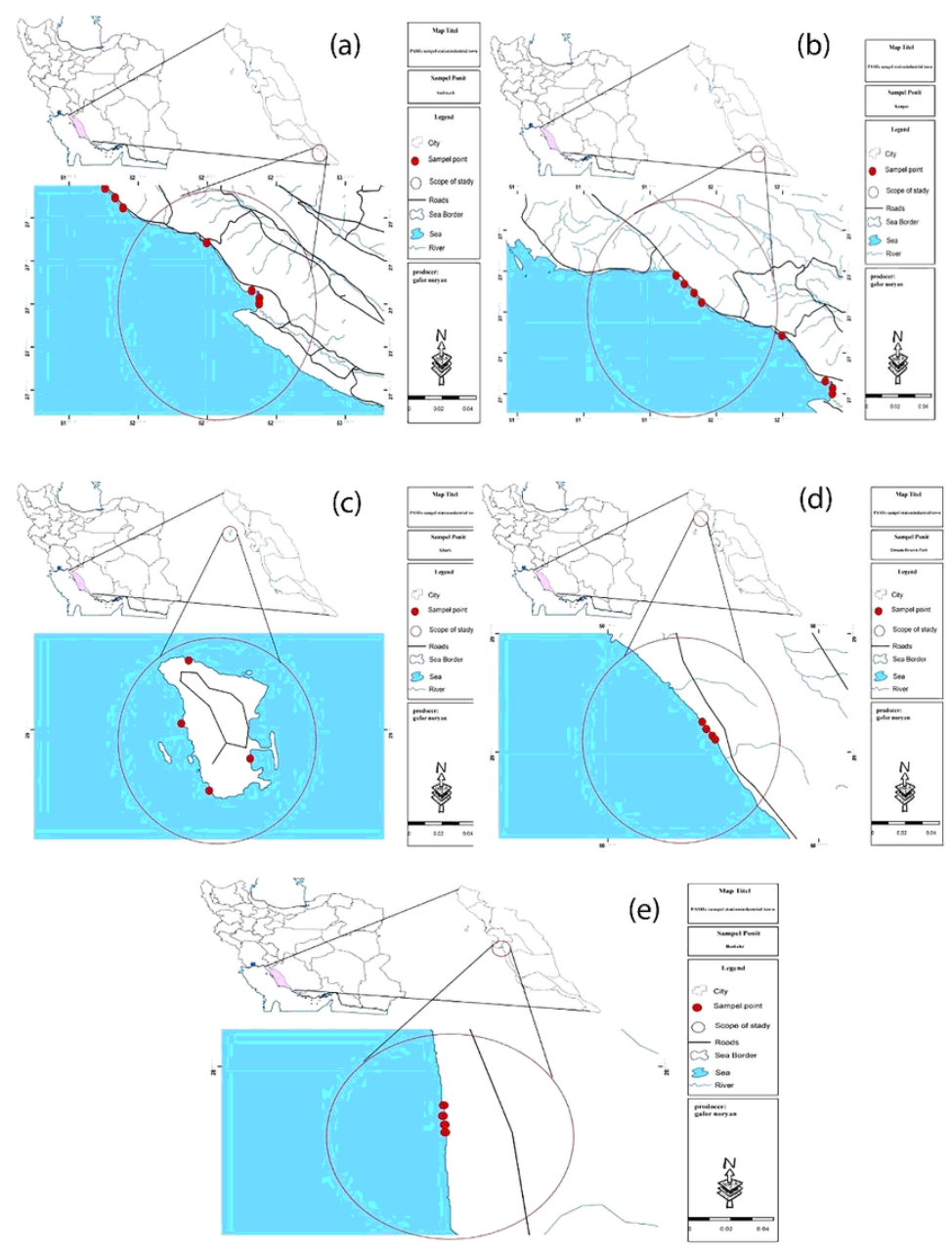

\section{Figure 1}

The studied areas and sampling locations (a) Assaluyeh, (b) Kangan, (c) Khark, (d) Emam Hasan, and (e) Bushehr stations Note: The designations employed and the presentation of the material on this map do not imply the expression of any opinion whatsoever on the part of Research Square concerning the legal status of any country, territory, city or area or of its authorities, or concerning the delimitation of its frontiers or boundaries. This map has been provided by the authors.

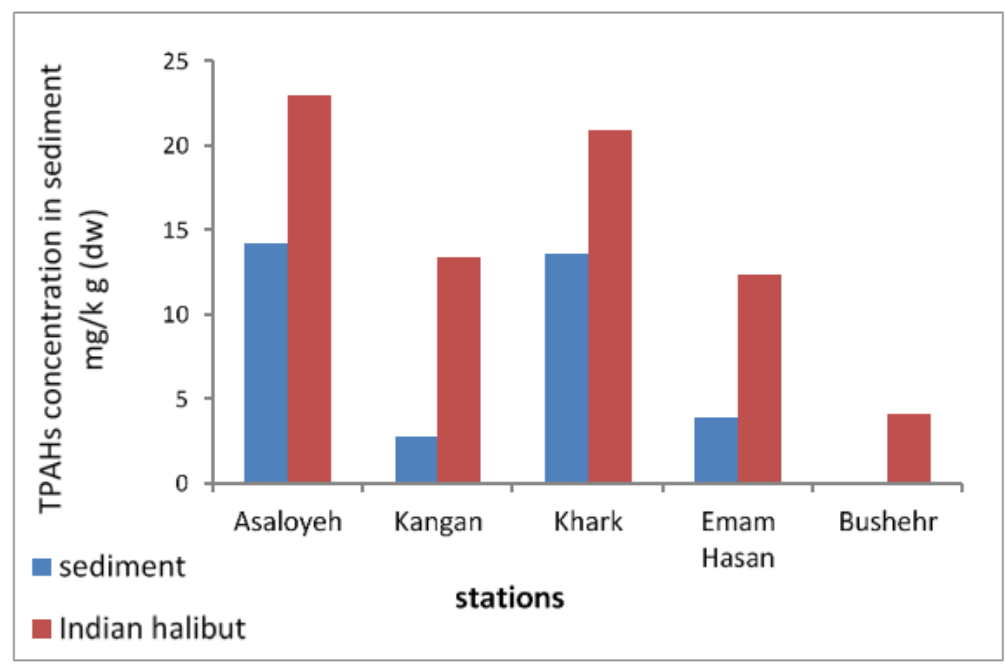

\section{Figure 2}

Regional differences between PAHs at sediment and Indian halibuts 

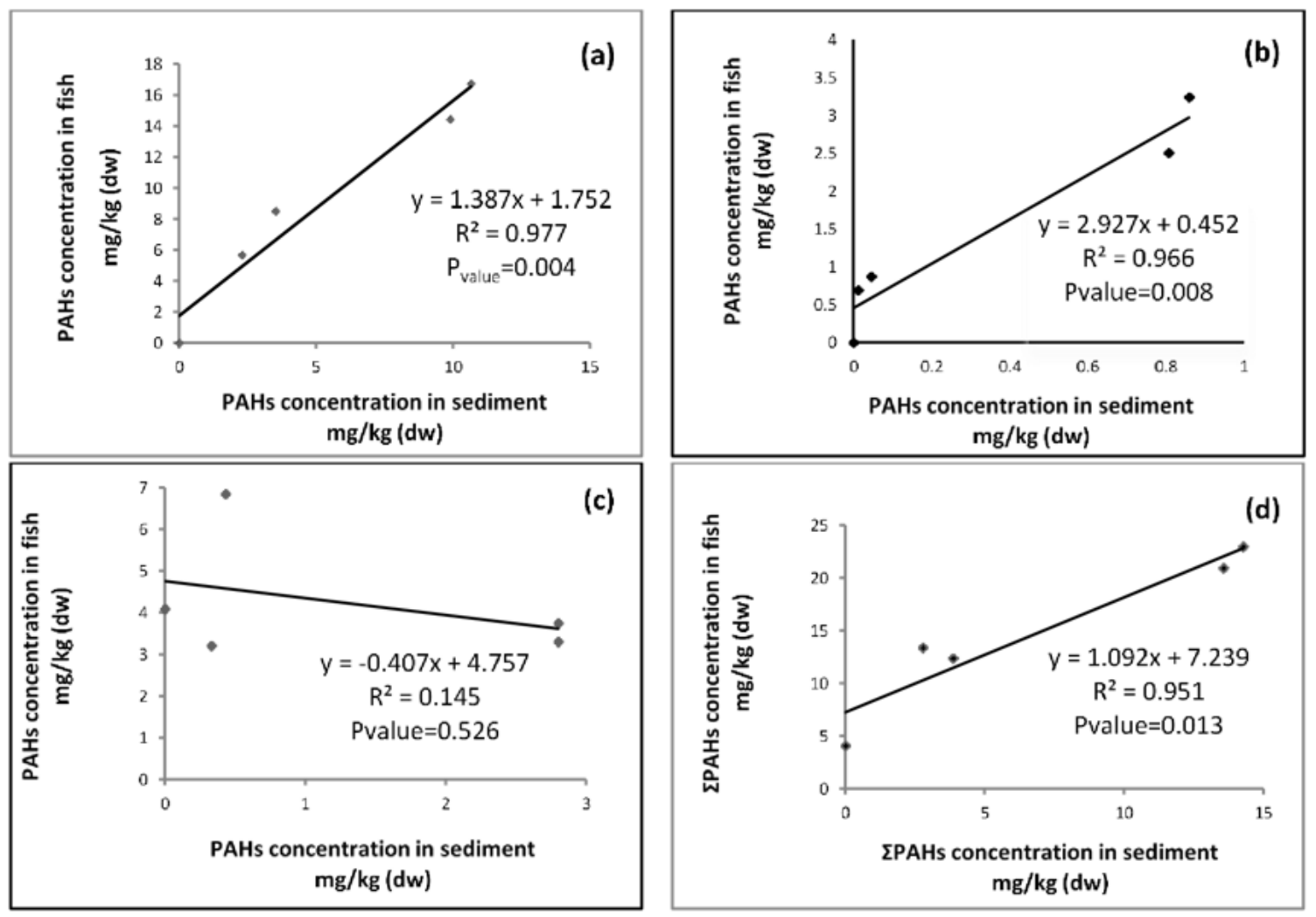

Figure 3

Correlation between the total concentration of PAHs, compounds 2 and 3 ring and 4 rings in the sediments and the edible part of Indian halibuts (a) Assaluyeh, (b) Kangan, (c) Khark, (d) Emam Hasan
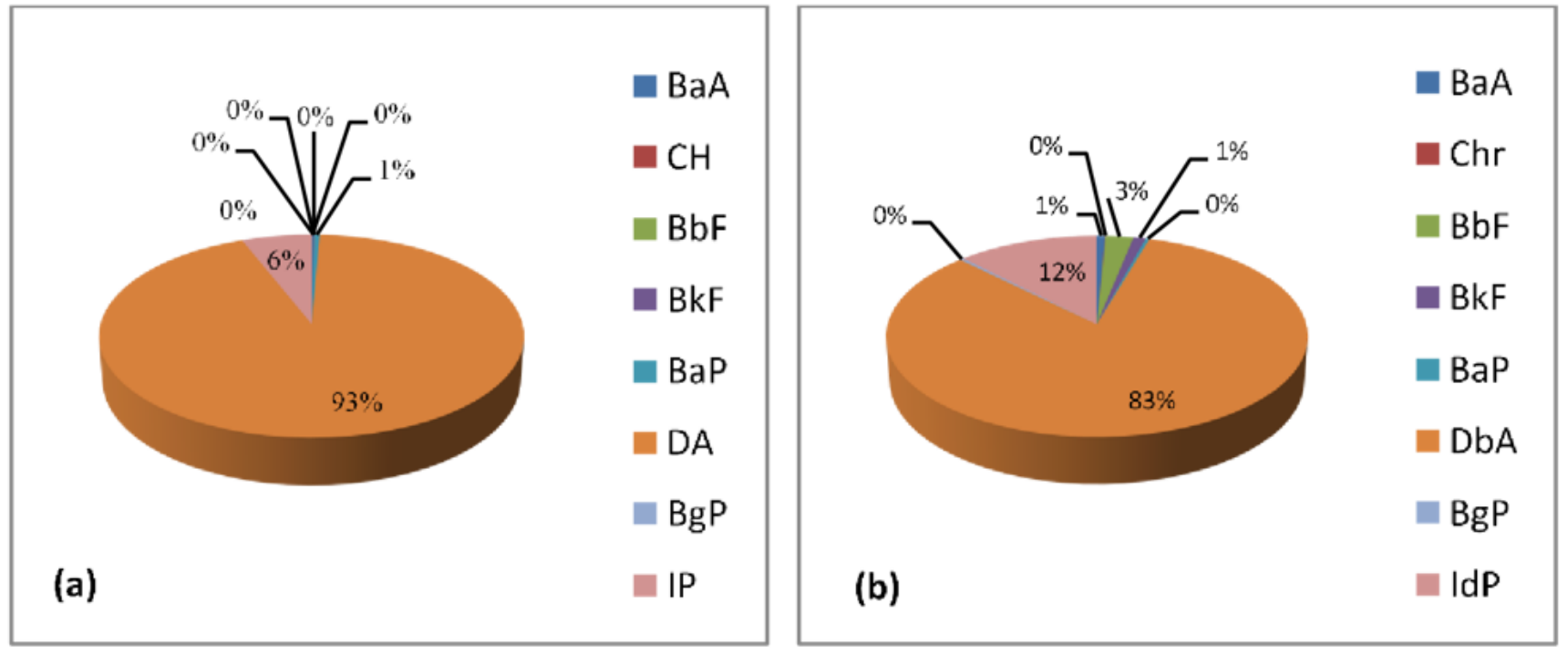

\section{Figure 4}

Share of single PAHs for carcinogenic potencies in sediment (a) and Indian halibuts (b) samples 